\title{
Conservation of Saint Paul Church, Thailand
}

\author{
Siriwan Silapacharanan \\ Faculty of Architecture, \\ Chulalongkorn University \\ Phyathai Road, Pathumwan, Bangkok 10330, Thailand \\ siriwan.s@chula.ac.th
}

\begin{abstract}
There are very few Catholic churches in Thailand that conserve wooden structures. The first church of St. Paul was made of bamboo and the other timber on the Bang Pakong River. In 1873, Father Schmidt Francois-Joseph built the third one with concrete including wooden structures such as priest quarters, a bell tower, a rest pavilion, a granary, a school building, all of which were designed by French priests in colonial architecture and constructed by Chinese workers. As present, these buildings have been deteriorating. However, their conservation plans have been launched, recently.

Keywords: conservation; Catholic Church; colonial architecture; timber

eISSN 2398-4295 @ 2017 The Authors. Published for AMER ABRA by e-International Publishing House, Ltd., UK. This is an open access article under the CC BY-NC-ND license (http://creativecommons.org/licenses/by-ncnd/4.0/). Peer-review under responsibility of AMER (Association of Malaysian Environment-Behaviour Researchers), ABRA (Association of Behavioural Researchers on Asians) and cE-Bs (Centre for EnvironmentBehaviour Studies), Faculty of Architecture, Planning \& Surveying, UniversitiTeknologi MARA, Malaysia.

http://dx.doi.org/10.21834/ajbes.v2i8.52
\end{abstract}




\section{Introduction}

The ICOMOS Charter on the built heritage mentions that Vernacular building is the traditional way by which communities house themselves. (ICOMOS, 1999) Consequently, it can be changed and adapted depending on the socio-economic situation. In Thailand, there are some studies which are in line with this project. First, there is a study of the three ethnic communities in Chachoengsao, which is in relation to the Québec Declaration on the "Preservation of the Spirit of Place" (Silapacharanan and Monkolpradit, 2011). Second, the identity of water-based community refers to "the special characteristics lies in its resident way of life which is closely related to their geographical setting and its culture" (Silapacharanan, 2013). Third, a case study of Samut Songkhram Province found that the identity of the community resulted from the balance of the interaction among environment, socio-economic and culture of the residents. (Panitchpakdi, 2011)

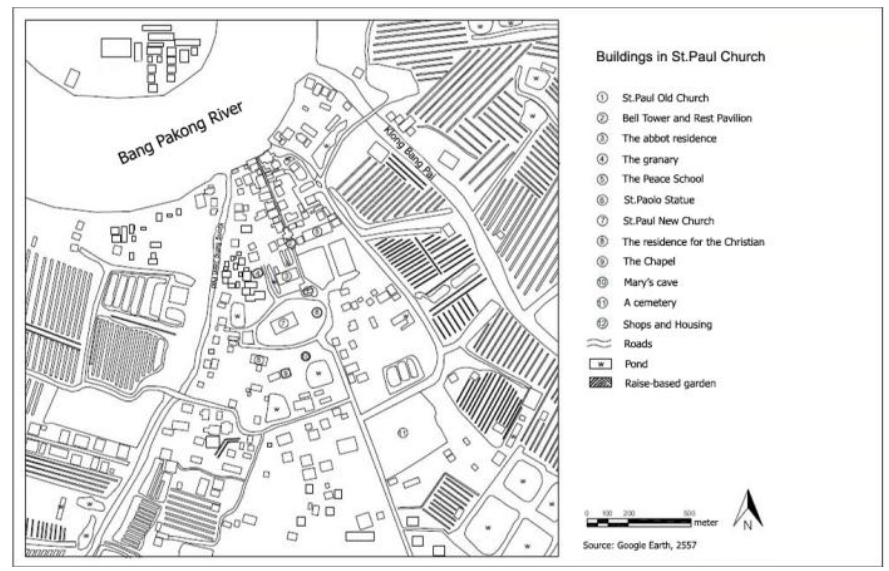

Figure 1: Map of Buildings in St.Paul Church

Most community structures in Southeast Asian were built of timber. In Thailand, timber or wood was a commonly found as basic material in the past for residential building as well as religious ones; as a result, most buildings - house, pavilion, monastery, bell tower - were made of wood. Other old wooden Catholic churches can be seen in St.PhilipJames Catholic Church, Chonburi Province and St.Roch Church in Chachoengsao Province. Another wooden monastery in St.Michael Church Song Yae, Yasothorn Province in the Northeastern Region. The latter was built in 1947, and now it is a cultural tourist attraction.

The St. Paul Church is located in Chachoengsao Province, and it is the first Catholic Church on Bang Pakong River. There are many wooden buildings in this church that are unique and valuable in terms of cultural heritage. Even though, the building conditions are deteriorated. (Figure 1) In general, Thai people often look back to their heritage and realize 
how important it is as a basic of their identity (Kanjanusthiti, 1988). The Saint Paul church community people performed the same way, and they can participate to revive their cultural heritage actively. The church was awarded the outstanding architectural conservation in 1990 for community category and in 1991 for building category by the Association of Siamese Architects under the Royal Patronage.

The objectives of this project are to 1) conserve the culturally significant buildings, 2) involve both the community and the stakeholders in this project and 3) transform the historical site into a cultural tourist attraction.

\section{Methodology}

There are four steps of the conservation procedure of this action research.

\section{Step I. Inventory of cultural heritage}

The research was funded by the Office of Natural Resources and Environmental Policy and Planning in 2007. The activities were:

1. Studying on history and cultural heritage of the community,

2. Organizing meetings with the community in order to inform the project proposal and ask for local participation,

3. Field surveying and doing a draft measure work of the five wooden buildings of the church: the abbot residence, the granary, the bell tower, the rest pavilion, and the former chapel,

4. Printing a book entitled "Cultural Heritage Environment Atlas of Saint Paul Church Community, Muang District, Chachoengsao Province" for references.

\section{Step II. Planning for cultural heritage conservation}

The research works had been funded by Chulalongkorn University in 2010-2012. The main activities were:

1. Prioritizing the five wooden buildings for restoration,

2. Fundraising for both money donation and construction materials,

3. Organizing meetings with the church and local people to plan for the conservation project,

4. Print a book entitled "Thai Traditional Way of Living: Community Spirit along the Bang Pakong River" for references.

\section{Step III. Implementation of building conservation}

The research works have been done during the year 2013-2016 and funded by the National Research Council of Thailand. The main activities are as follow. 
1. Conservation of buildings, the abbot house in 2013 , the wooden bell tower and the rest pavilion in 2014, the old chapel in 2015-2016 and, the granary in 2016.

2. The request for construction materials of paint products, roof tiles, floor tiles from manufacturers and distributors is essential since it can reduce the cost of conservation.

3. The conservation of buildings in the church has to be approved by the Church Council and the Diocesan Bishop. The Christians and individual donate some money for restoration.

4. Strengthen the community awareness to maintain their heritage.

\section{Results and Discussions}

\section{The Wooden Structures in the Church}

At present the St. Paul community possesses the Roman Catholic identity - the old church, the new church, St. Paolo statue, the bell tower and the rest pavilion on the river, a school, a cemetery, Mary's cave, the priest quarters, the chapel, the granary, and residence for the Christian. This article deals with the five wooden structures or timber heritage left in the church, which includes the bell tower, the rest pavilion, the abbot residence, the old chapel and the old granary.

Most of the timber heritages were the works of Father Schmidt, Father Perbet and Father Carrière, who were priest and abbots in the St. Paul Church during mid $19^{\text {th }}-$ mid $20^{\text {th }}$ century. Father Jean Carrière, skillful in mathematics, acted as an architect and designed several Colonial architectural wooden buildings in St. Paul Church. Chinese artisans constructed these teak buildings. The material is suitable for the weather and relocation. These buildings are the timber heritage of the St. Paul Church.

\section{The Bell Tower and the Pavilion}

The 16-meter-high wooden bell tower was built during the reign of King Rama V (18681910). The tower is in a square shape -4 meters each. The wall is made of wood. The base of the tower is in the shape of the cross with 10 meters wide on each side. The height of the tower is about the same height as a three-story building and steps are leading to the three bells - a small bell (soprano voice), a medium bell (average voice) and a big bell (alto voice). Built in Dijon, France in 1897, all of them were made of bronze and engraved with a picture of a priest and an inscription 'Mission de Petriou'. The name of Father Perbet was on the big bell. (Figure 2)

Next to the tower is the rest pavilion that is made of teak. There are 1.20 -m-high teak balustrades around the rest pavilion except the walkway. The roof is in a square shape with four gable ends. The floor plan is in the shape of the cross with the width of 10.50 meters and the length of 14.00 meters. (Figure 3) 
Silapacharanan, S. / Asian Journal of Behavioural Studies, AjBeS, 2(8), Oct / Dec 2017 (p.33-42)
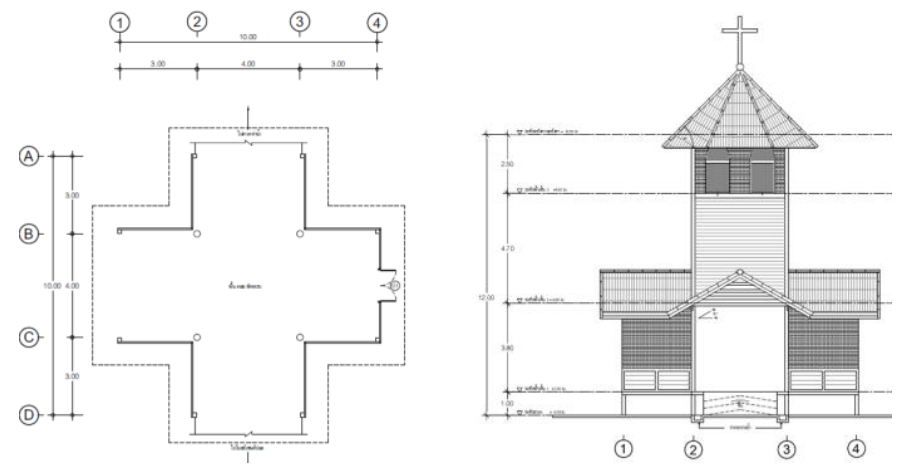

Figure 2: Floor Plan and Front Section of the Bell Tower
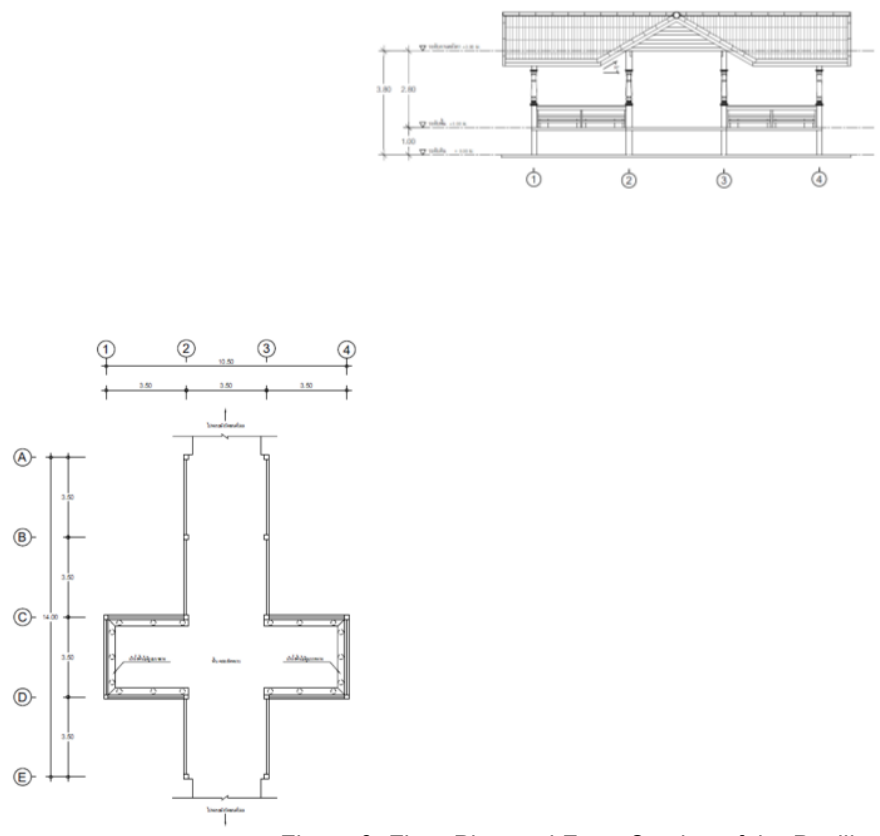

Figure 3: Floor Plan and Front Section of the Pavilion 
Since the tower represents the community way of life and the religion, the renovation of the tower and the rest pavilion has been carried out and paid by the donation from a family. (Figure 4)
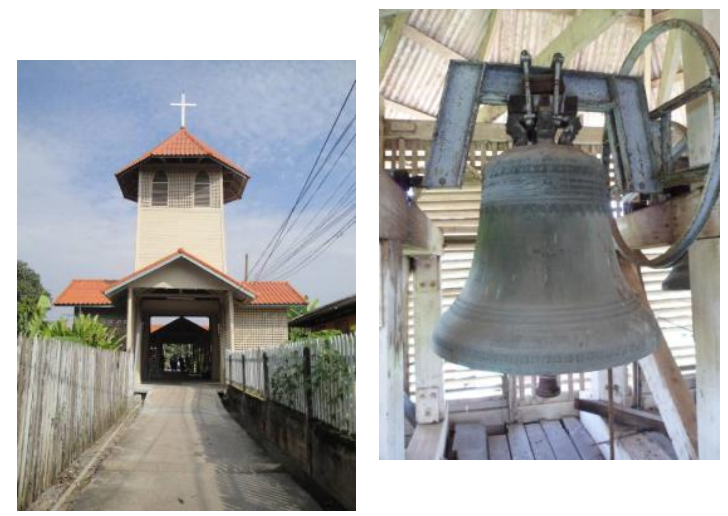

Figure 4: The Bell Tower and the Rest Pavilion

\section{Abbot Residence}

Made of teak with the length of 15 meters and the width of 30 meters, the residence was built during the reign of King Rama V (1868-1910). Designed by Father Jean Carrière, it was constructed by Chinese men and its architectural style was of the Colonial Architecture. It is a two-story house with steps on the left and the right side. There is a corridor on the second floor and wooden balustrades around the house. On the side and the back of the house are the window shutters of 0.65 meter in length and 2.40 meters in width. There is an open space in the middle of the house flanked by rooms. The rooms on the first floor are parallel to those on the second. This house is more than 130 years old and in the past besides being the abbot's residence, other priests that traveled past the church could stay overnight here. (Figure 5)

\section{The Old Chapel}

This chapel was used by those who taught girls who wanted to be nuns for a certain amount of time. In 1947, it accommodated female orphans but at present, it is for storage. It is a wooden building with an elevated floor, 12 meters in length and 23 meters in width. Its hip roof is 12 meters long and 16 meters wide. Long wooden balustrades from the floor to the ceiling are placed around the building for safety purpose. The steps leading to the second floor are on the corners of the building, and these steps are equipped with doors that can be closed from the inside. The front steps were removed. After the renovation in 
2016, it will be used as the museum of belief with the partial fund for the exhibition from the Ministry of Culture. (Figure 6 and 7)

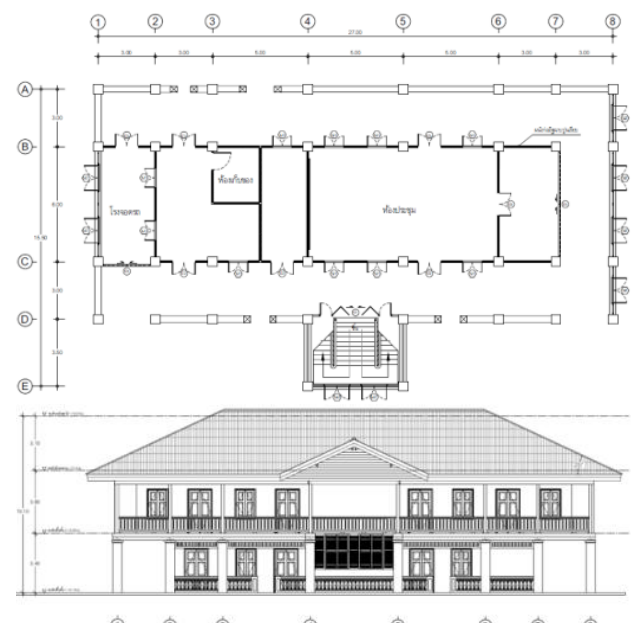

Figure 5: Floor Plan and Front Section of the abbot residence
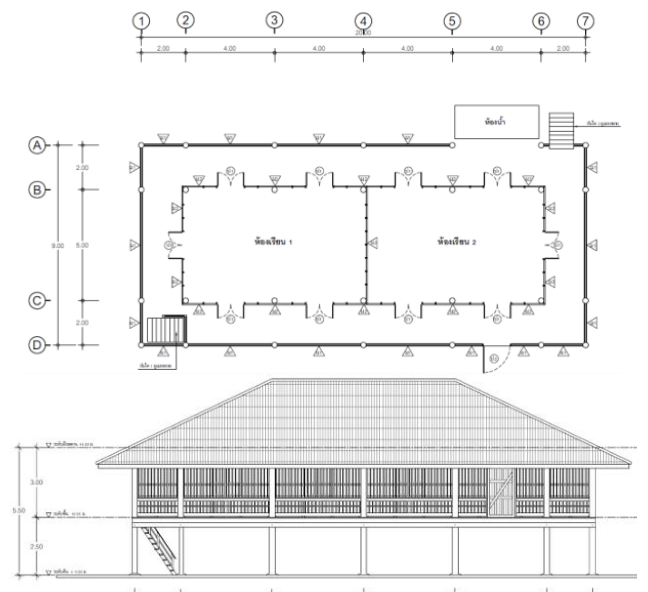

(1) (2)

(3)

(4)

(5)

(6) (7)

Figure 6: Floor Plan and Front Section of the old chapel 


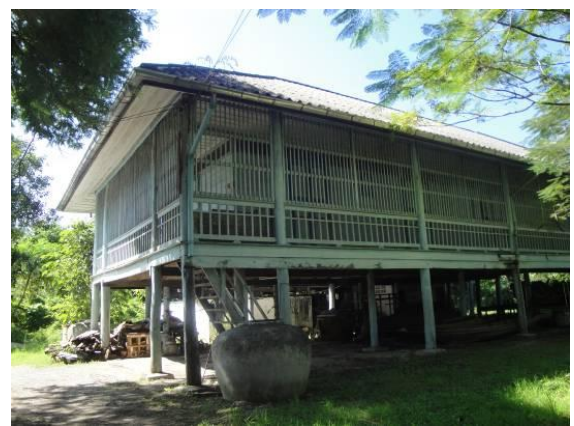

Figure 7: The Old Chapel

\section{Granary}

18 meters long and 10 meters wide, it was built to store rice taken from the St.Roch church's rice fields on the opposite side of the river. The farmers who rented the rice fields gave some paddies to the church as the rental fee. In the past, the rice has been paid to the orphans and those living in the church. Later, new dioceses are assigned by using the Bang Pakong River as division; consequently, the rice fields do not belong to the church. At present, under the restoration and it will be used as a cultural learning center of the church. (Figure 8 and 9)
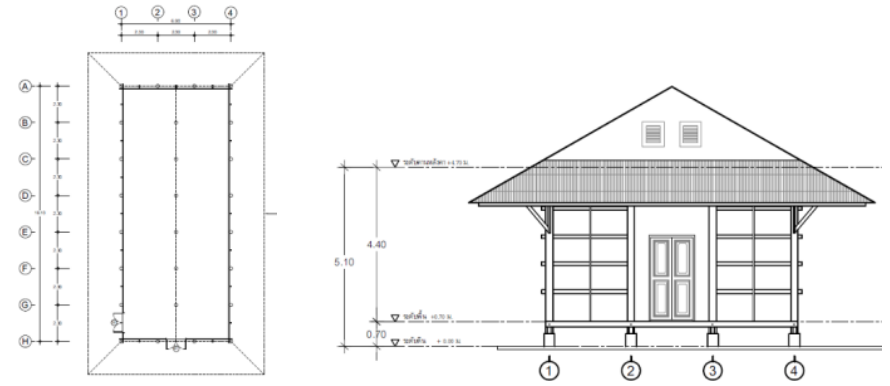

Figure 8: Floor Plan and Front Section of the granary

The experience of this action research reveals that participation in different partnership: the church, the Catholic community, public and private agencies, is an influential factor to realize this conservation project though it would take almost nine years. This research is in line with the community conservation project in Amphawa, Samut Songkhram in Thailand for participatory importance. (Wannasilpa Peerapun, 2012) 


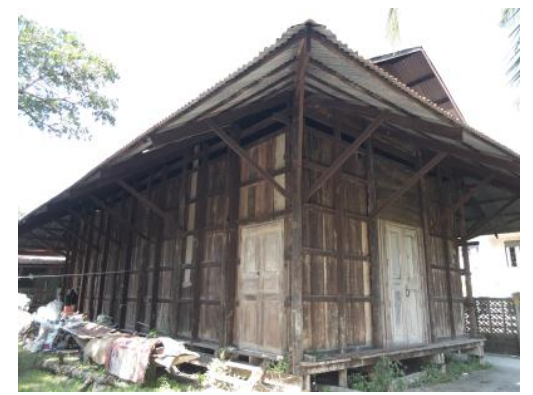

Figure 9: Granary

\section{Conclusion}

It can be concluded that St. Paul Church possesses strong cultural identity. The vernacular architecture was founded by a French priest and most of the community members around the church are descendants of the Chinese immigrants.

The project has been carried out by 1) raising the community member's awareness through various activities such as meetings with the Church and community members and the church council, 2) inviting the church, community members, government agencies and the private sector to participate in the project, 3) raising funds for renovating old buildings such as the missionary housing the chapel, the bell tower, the wooden pavilion, the granary 4) adapting the function of the old buildings such as transforming the rice barn into a learning center of local community and the chapel into a religious museum displaying the items which the church and the community members have collected and 5) improving the landscape of the Church and the community. With the completion of the project, this community will be regarded as a cultural tourist attraction that can be accessed by both water and land routes. Presently, the church and the community are jointly working with other sectors to conserve this timber heritage as an identity of their cultural heritage.

\section{Acknowledgement}

This research is funded by the Research Council of Thailand under Project Plan "The Architecture for Community Empowerment".

\section{References}

Kanjanusthiti, P. (1988). Conservation of Historic Building in Thailand, Manusaya: Journal of Humanities, 1(2), 1988, 47-71.

Pallegoix, Mgr. (1854). Description du Royaume du Siam. Paris. 
Panitchpakdi, K. (2011). The Sustainability of Local Community under the Globalization: The Case of Kao Yi Sarn, Samut Songkram, Thailand. Procedia - Social and Behavioral Sciences, 36, 2012, 361-371.

Peerapun, W. (2011). Participatory Planning in Urban Conservation and Regeneration: A Case Study of Amphawa Community. Procedia - Social and Behavioral Sciences, 36, 2012, 243-252.

Silapacharanan, S. and Mongkolpradit W. (2011). Community Responses to Cultural Identity of the Three Religious Communities: A Case Study in Chachoengsoa Province, Thailand. Procedia - Social and Behavioral Sciences, 36, 2012, 723-731.

Silapacharanan, S. (2013). The Identity of Water-based Communities in Thailand. Procedia - Social and Behavioral Sciences, 85, 2013, 27-32.

UNESCO Bangkok. Timber Heritage. (2015). available on: http://unescobkk.org/culture 